\title{
A nanofluidikai atomerőmikroszkóp: FluidFM
}

\author{
Nagy Ágoston Gábor ${ }^{1), 2)}$, Bonyár Attila ${ }^{2)}$, Horváth Róbert ${ }^{1)}$ \\ ${ }^{1)}$ MTA EK MFA Nanobioszenzorika Lendület Kutatócsoport \\ 1121 Budapest, Konkoly-Thege M. út 29-33, 26. épület 2. emelet 205 \\ 2) Budapesti Müszaki és Gazdaságtudományi Egyetem \\ Elektronikai Technológia Tanszék, 1111 Budapest, Egry József u. 18. \\ E-mail: ag.nagy@ett.bme.hu
}

Tartalmi kivonat. A FluidFM technológiája kombinálja a hagyományos atomerö mikroszkópot nanofluidikai csatornák és egy nyomásszabályozó eszköz rendszerével, mely fejlesztéssel a müszer átlép olyan méréstechnikai korlátokat, amelyek korábban csak magas technikai tudással és jelentös időráfordítással voltak elérhetöek. A FluidFM berendezés által lehetövé válik nanotechnológiai és elö sejtes rendszerek interdiszciplináris vizsgálata, ami által betekintést nyerhetünk olyan elemi részletekbe, mint például a sejtadhézió vagy pedig a nanostruktúrák hatásai az élö rendszerekre.

Kulcsszavak: FluidFM; atomerö mikroszkóp; nanofluidika; szílícium technológia; nanolitográfia

\section{A FLUIDFM TÖRTÉNETE}

A nanofluidikai atomerö-mikroszkóp technológiáját először 2009-ben írták le részletesen [1]. A nanofluidikával ellátott atomerö-mikroszkóp kutatása és technikai hátterének kidolgozása a 2000es évek elején indult, azonban az eszköz kereskedelmi forgalomba hozatalában és fejlesztésében nagy szerepet játszott a Cytosurge AG, mely cég a zürichi technológiai föiskola (ETH Zürich) spin-off cége. A „fluidic force microscope”, avagy rövidebben FluidFM kombinálja a hagyományos atomerő mikroszkópot (atomic force microscope, AFM) nanofluidikai csatornák szabályozott rendszerével [1]. Az AFM technológiájának kidolgozásáért 1986-ban ítélték oda a fizikai Nobel-díjat, és a müszer azóta is széleskörü népszerüségnek örvend, mivel nagy (akár atomi) felbontású képalkotást tesz lehetővé. Alkalmazása kiterjed az anyagtudományra, a müszaki tudományokra és az élettudományok számos területére is. Manapság számos alap és alkalmazott kutatási irányban az AFM rutinberendezésnek számít, amellyel felületi topográfiát és felületi fizikai kölcsönhatásokat (elektrosztatikus erő, mágneses erő, vezetőképességtérképek, mechanikai tulajdonságok, stb.) lehet precízen leképezni, akár egyedi atom felbontással.

$\mathrm{Az}$ AFM talán legfontosabb része egy piezoelektromosan mozgatott, ismert geometriájú és igen hegyes tü (görbületi sugara ma már akár $10 \mathrm{~nm}$ alatti), amely a vizsgálni kívánt felszínt pásztázza végig. Technikailag ez a tü egy ismert rugóállandóval rendelkező tartókonzolra, ún. rugólapkára van erősítve és így közösen alkotják a szondát. A rugólapkára irányított fókuszált lézerfény visszaverődésének valamint kitérésének detektálása teszi lehetővé a szondát érő erőhatások precíz leképezését. Topográfiai leképzéseknél a tű és felület között fellépő atomi vonzó és taszító kölcsönhatások játszanak szerepet, melyek a rugólapka elhajlását és így a visszaverődött lézerfény kitérését okozzák, melyet egy fotodetektorokból álló elrendezés érzékel [2]. Ennek köszönhetően tud az AFM mechanikai kölcsönhatásokat is kimérni, mert ha meghajlik a rugólapka, akkor a lézerfény arányos kitérése adja a számunkra értelmezhető fizikai paramétert.

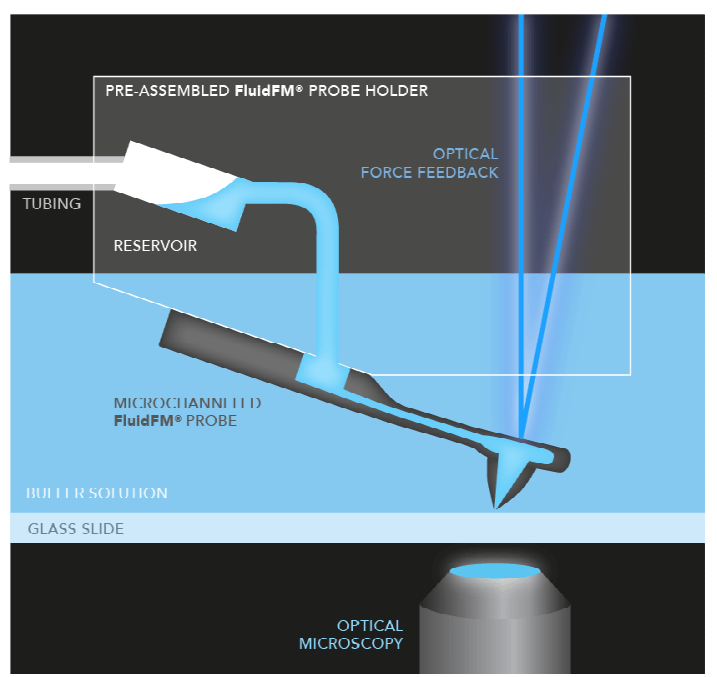

1. ábra. A FluidFM kombinálja az AFM technológiáját nanofluidikai csatornákkal. A mérőszonda képes pikoNewtonos erőhatások kimérésére [3] 
A FluidFM lényegében egy AFM berendezés, melynek pásztázó fejébe bevezettek egy nanofluidikai csatornát, amit összekapcsoltak egy nyomásszabályozó rendszerrel, így képesek vagyunk -800 és $1000 \mathrm{mBar}$ között szabályozni a csatornában lévő folyadékoszlop mozgását. Ezen fejlesztéssel teret nyitottak a szélesebb körü felhasználásra, mint például kolloidális spektroszkópiára, élő sejtes vagy bakteriális rendszerek valós idejủ mechanikai manipulációjára, illetve nanolitográfiás eljárásokra [3] (1. ábra).

\section{A FLUIDFM MÉRŐFEJEK ELÖÁLLÍTÁSA}

A FluidFM lehetőségeinek kiaknázását többféle kialakítású mérőfejek teszik lehetővé, melyek össze vannak kötve a folyadékmozgató rendszerrel. Először 2004-ben készítettek először nanofludikával ellátott tűket [4], mely eljárás hasonló az AFM tűk gyártásához. Általában a tük alapanyaga egykristályos szilícium vagy szilícium-nitrid (SixNy), melyet a klasszikusnak nevezhetö fotolitográfiával kombinált anizotróp kémiai maratással alakítanak ki. A külön kialakított bemélyedéseket tartalmazó $\mathrm{Si}$ mikroszerkezetek bondolásával (ragasztásmentes kötésével) alakítják ki a mérőfejeket úgy, hogy bennükfusson a nanofluidikai csatorna. A konzolok legfontosabb paramétereit - a rugóállandót és a rezonanciafrekvenciát - a konzol geometriai paramétereivel valamint a SiN-aránnyal, mint anyagi jellemzővel, lehet széleskörűen szabályozni. A konzolok rezonancia frekvenciája általában 1 kHz-től 1MHz-es tartományban mozog és a rugóállandójuk 0,01-től egészen $50 \mathrm{~N} / \mathrm{m}$-ig terjed. Jellemzően puhább (kisebb rugóállandójú) szondát kapunk, ha magasabb szilícium-nitrid tartalmat alkalmazunk a készítés során. A csúcsos háromszögben végződő hasáb a konzol tipikus geometriája, melynek a végén található a 15 nm-nél kisebb lekerekítési sugarú tủ. A FluidFM mérőfejei is a hagyományos SixNy vegyületből állnak, és egy ilyen rugólapkán egy-vagy akár többcsatornás rendszerek is kiépíthetők. A nanofluidikai csatornák kivezetőnyílása általában egy piramis csúcsán vagy mellette elhelyezkedő nyílás, amit fotolitográfiával, vagy fókuszált ionnyalábos anyageltávolítással állítanak elő [4].

\section{A FLUIDFM KÜLÖNBÖZŐ TÍPUSÚ MÉRÖFEJEINEK ALKALMAZÁSA}

A FluidFM három típusú mérőfejjel rendelkezik, amelyekkel különböző alkalmazások és kísérletek valósíthatók meg (2. ábra). A FluidFM mikropipetta feje nem rendelkezik tüszerü struktúrával a konzol végén, csupán egy kör alakú kivezető nyílás ad utat a fluidikának. Ezek a mérőfejek elsősorban sejtadhéziós mérésekre lettek kifejlesztve (2. ábra. a)), segítségével sejtmechanikai erőhatásokat tudunk mérni a piko-Newtonos skálán. A mikropipetta mérőfej kivezetése 2-8 $\mu$ m átmérőjü, azonban amíg ez az átmérő is meglehetősen kicsinek számít, addig a FluidFM nanopipetta mérőfejének átmérője $300 \mathrm{~nm}$, mely mérőfej hagyományos tűszerü struktúrájú és a piramis csúcsán helyezkedik el a fluidika kivezető nyílása (2. ábra. d)). A nanopipetta mérőfeje leginkább bakteriális adhézió méréséhez vagy nanolitográfiához használatos. A legkisebb átmérőjü mérőfej a gyorsprototipizáló fej, melynek kivezető csatornája $30 \mathrm{~nm}$-es átmérőjű és elsősorban femtoliter mennyiségü folyadékok célzott célbajuttatásáért felel (2.ábra. c)). Segítségével képesek vagyunk sejteket megjelölni fluoreszcens festékekkel, vagy esetleg gyógyszermolekulákat célzottan a sejttesten belülre fecskendezni.

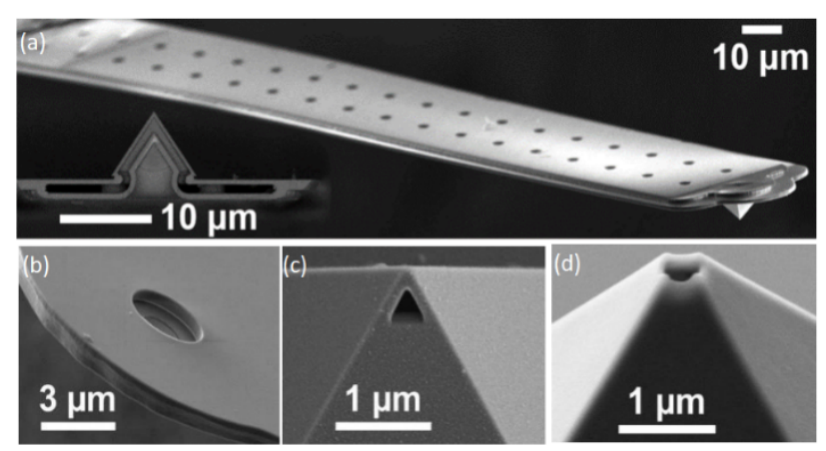

2. ábra. A FluidFM mérőfejek elektronmikroszkópos képei: a) a FluidFM mérőszondájának geometriai elrendezése; b) a mikropipetta mérőfej; c) a gyorsprototipizáló mérőfej; d) a nanopipetta mérőfej [5]

\section{A FLUIDFM JöVöJE}

Habár a technológia már egy évtizede ismert és a rendszert, valamint a belőle származó eredményeket már több rangos nemzetközi folyóiratban is publikálták [6,7], valóságos fellendülés következhet be technológiai újításoknak köszönhetően. A FluidFM müködési sokoldalúsága erős 
háttértámogatást nyújthat interdiszciplináris kutatásoknak, hiszen számos funkciója rávilágíthat eddig nem vizsgált, sőt esetleg ismeretlen eredetü jelenségekre. A Cytosurge AG. egyik legújabb fejlesztése a FluidFM Bot, amely egy nagyáteresztőképességü robotizált FluidFM berendezés, melynek segítségével képesek vagyunk automatizált méréseket végezni. Például amíg a sejtadhézió területén korábban csak 1-2 mérés volt lehetséges a technológiai korlátok miatt, a FluidFM Bot akár 10-20 mérést is képes kivitelezni egy órán belül (3. ábra). A fekete színü szonda egy sejtkultúra felett adott parancsra megközelíti a mérni vagy manipulálni kívánt egyedi élő sejtet (piros kör), amelyhez $\mu \mathrm{m} / \mathrm{s}-o s$ sebességgel közelít. Amikor elérte a kívánt felület és szonda között kialakult erőhatást (kb. $3 \mathrm{nN}$ [1]), akkor szívó hatást fejt ki a szétterült sejtre. Egy kis várakozás után eltávolodik a felszíntől és felszakítja a sejtet az aljzatról. Nyomás ráadásával a mért sejt eltávolítható a konzolról. Utóbbi folyamat során meghatározható a sejt adhéziós ereje és adhéziós energiája (4. ábra).

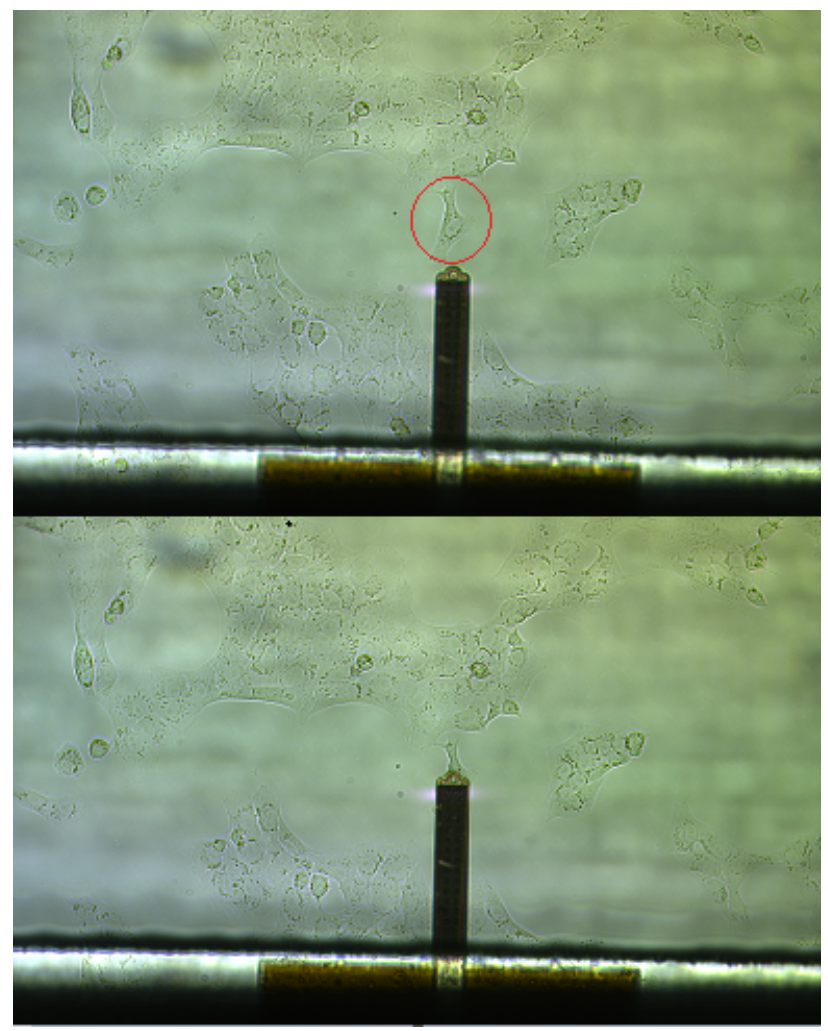

1. ábra. A FluidFM adhéziómérés közben

A magyar kutatási életben is jelen van ennek a technológiának az alapkövei, ugyanis Dr. Horváth Róbert által vezetett MTA EK MFA Nanobioszenzorika Lendület Kutatócsoportban üzemeltek be egy új FluidFM Bot-ot 2017-ben. A csoport célja olyan jelölésmentes, modern biofizikai módszerek fejlesztése és alkalmazása az élettudományok különböző területein, amelyek ipari és tudományos szignifikanciával bírnak [8].

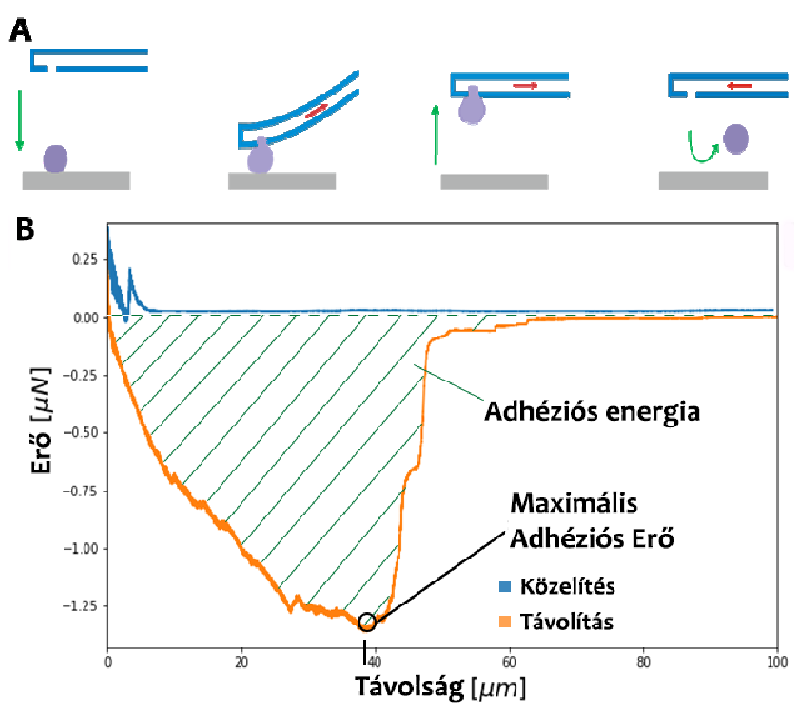

4. ábra. Sejtadhézió mérés: a) sejtadhézió mérésének folyamata [3]; b) a FluidFM segítségével minden sejtre egyedi jellegü erő-távolság görbét tudunk kimérni, amelyből számos információ kinyerhető

A FluidFM müködésének kulcsfontosságú pontja a precízen szabályozott nanofludikai rendszer, mellyel egyszerre tudunk szívást illetve nyomást kifejteni az adott rendszerre, és ezáltal vagyunk képesek nanolitográfiás nyomtatásra, élő organizmusok sérülésmentes „megfogására” és felületi kitapadásaik kvantitatív vizsgálatára, mikroszkópikus objektumok nagy precizitású mozgatására. Túllépve az AFM korlátait, a FluidFM olyan automatizált, minimális anyagmennyiségü mérésékre ad lehetőséget, melyeket korábban csupán nagy körültekintéssel vagy egyáltalán nem lehetett megoldani. Hasonló nanofluidikai rendszerek már bizonyítottan jelen vannak a mindennapi orvosi diagnosztikában, mint például a „lab-on-chip” eszközök, melyek a gyors, hordozható és megbízható diagnózis felállításában segédkeznek. Elképzelhető, hogy a FluidFM technológiáját hamarosan a klinikai diagnosztikában is alkalmazni fogják, ugyanis számos kutatás korrelációt mutatott ki a sejtek rugalmassága és gyulladásra, vagy tumoros elváltozásra való hajlamuk között $[9,10]$. Ilyen és hasonló biológiai információk kvantitatív tanulmányozására kifejezetten alkalmas a FluidFM, mert pl. egyszerüen, kis mintamennyiségből meg lehet határozni, hogy egy adott páciens sejtjei 
milyen tumorokra jellemző rugalmassági paraméterekkel rendelkeznek, és ezért a technológia segíthet egy korai diagnózis felállításában is. Továbbá mivel a FluidFM képes femtoliteres folyadék mennyiségek célzott célbajuttatására, ezért lehetőség nyílik minimális anyagfelhasználás mellett rákos sejteket tesztelni, hogy milyen tumorellenes gyógyszerekre rezisztensek vagy érzékenyek, és így a FluidFM technológia költséghatékony és újszerü utakat nyithat meg a hatékonyabb terápiák kidolgozásában is.

\section{IRODALOMJEGYZÉK}

[1] Meister A., Gabi M., Behr P., Studer P., Vörös J., Niedermann P., Bitterli J., Polesel-Maris J., Liley M., Heinzelmann H., Zambelli T., „FluidFM: Combining Atomic Force Microscopy and Nanofluidics in a Universal Liquid Delivery System for Single Cell Applications and Beyond", Nano Lett., 9. évfolyam, 6. szám, 2501-2507 o., 2009. https://doi.org/10.1021/n1901384x

[2] Binnig G., Quate C.F., Gerber C., „Atomic Force Microscope", Phys. Rev. Lett., 56. évfolyam, 930933 o., 1986.

https://doi.org/10.1103/PhysRevLett.56.930

[3] https://www.cytosurge.com/

[4] Deladi S., Tas N.R., Berenschot J.W., Krijnen G.J. M., de Boer M. J., de Boer J. H., Peter M., Elwenspoek M.C., ,Micromachined fountain pen for atomic force microscope-based nanopatterning", Appl. Phys. Lett., 85. évfolyam, 5361-5363 o. 2004. https://doi.org/10.1063/1.1823040
[5] http://smartmanufacturingseries.com/wpcontent/uploads/2017/10/zambelli.pdf (2017)

[6] Sancho A., Vandersmissen I., Craps S., Luttun A., Groll J., ,A new strategy to measure intercellular adhesion forces in mature cell-cell contacts", Sci. Rep., 7. évfolyam, 46152, 2017. https://doi.org/10.1038/srep46152

[7] Sankran S., Jaatinen L., Brinkmann J., Zambelli T., Vörös J., Jonkheijm P., ,Cell Adhesion on Dynamic Supramolecular Surfaces Probed by Fluid Force Microscopy-Based Single-Cell Force Spectroscopy", ACS Nano, 11. évfolyam, 38673874 o., 2017. https://doi.org/10.1021/acsnano.7b00161

[8] http://nanobiosensorics.com/

[9] Guillaume-Gentil O., Potthoff E., Ossola D., Franz C.M., Zambelli T., Vorholt J.A., ,Force-controlled manipulation of single cells: from AFM to FluidFM", Trends Biotechnol., 32. évfolyam, 7. szám, 381-388 o., 2014. https://doi.org/10.1016/j.tibtech.2014.04.008

[10] Cross S.E., Jin Y., Rao J., Gimzewski J.K., „Nanomechanical analysis of cells from cancer patients”, Nat. Nanotechnol., 2. évfolyam, 780783 o., 2007. https://doi.org/10.1038/nnano.2007.388 